\title{
Community by Necessity: Security, InSECURITY, AND THE FLATTENING OF Class in Fort McMurray, Alberta ${ }^{1}$
}

\author{
Claire Major \\ TraCY WinTERS
}

\begin{abstract}
High wages in the oil sands well exceed the Canadian average, making complex class differences less apparent here than elsewhere. This lends itself to a homogenizing narrative of community despite differences in wages, background, citizenship status, and so on. Wolf's useful counter-framework outlines specific processes by which workers are situated, and by which they situate themselves, in labour hierarchies within the accumulation process. Drawing on interviews and participant observation involving two groups (university-educated immigrant professionals and high-school educated mine labourers and tradespeople from Newfoundland), we argue that layers of precariousness in both these groups thrust them into "community by necessity." The unsettling nature of work in the oil sands emerges as a story within a story. In the larger narrative, where "Fort McMurray is jobs," community is invoked as a place in which household financial security is possible. Inherent in that security, however, is a story of pervasive insecurity wrought by the possibility of injury on the job, paternalism, or redundancies created through company restructuring and economic crises. "Community" is necessary to keep people in place (literally and metaphorically) and at the same time elides ongoing struggles against dispossession.
\end{abstract}

Keywords: class, immigration, Newfoundland studies

Résumé. Dans le secteur des sables bitumineux, la production est dominée par quelques grandes multinationales. Les salaires excèdent largement la moyenne canadienne, rendant les inégalités entre les différentes classes sociales moins apparentes qu'ailleurs. Alors qu'Harvey définit les tendances générales au chapitre du capital, Wolf décrit les processus particuliers selon lesquels les travail-

1. Acknowledgements. Tracy Winters gratefully acknowledges financial support from the Social Sciences and Humanities Research Council of Canada (SSHRC) and the Leslie Harris Centre of Regional Policy and Development, whose support made this research possible. Claire Major also acknowledges financial support from SSHRC as well as support from the Faculty of Graduate Studies and the CITY Institute at York University. Both authors thank the anonymous referees and the issue editors for their input, support, and guidance.

(C) Canadian Journal of Sociology/Cahiers canadiens de sociologie 38(2) 2013 
leurs sont classés et se classent eux-mêmes dans les hiérarchies du marché du travail, au sein du processus d'accumulation. Il s'agit là d'une approche utile pour expliquer comment la trame de la collectivité favorise l'homogénéisation, malgré les différences au chapitre des salaires, de l'expérience, du statut social, etc. D'après des entrevues avec deux groupes et l'observation de ces groupes (c'est-à-dire, d'un côté, des immigrants reconnus comme des professionnels titulaires d'un diplôme universitaire, et de l'autre, des Canadiens de souche diplômés du secondaire travaillant dans le secteur minier), nous avançons que les complexes relations entre les classes sociales s'estompent en quelque sorte à Fort McMurray, nivelées par l'hypothèse d'une collectivité unifiée. Nous suggérons que les divers niveaux de précarité inhérents à ces deux groupes les soudent en ce que nous appelons une « collectivité formée par nécessité ». De l'instabilité liée à la nature du travail dans le secteur des sables bitumineux émerge une histoire à l'intérieur d'une autre histoire. D'après le point de vue général selon lequel « Fort McMurray, c'est l'emploi », la collectivité prend le sens d'un endroit où la sécurité financière du ménage est possible. À cette sécurité se rattache toutefois une insécurité insidieuse, découlant notamment des risques liés aux accidents de travail, au paternalisme, aux licenciements entraînés par les restructurations de l'entreprise et aux crises économiques. Si la « collectivité » est essentielle pour garder les gens en place (au sens propre comme figuré), elle met toutefois de côté les incessantes luttes contre la dépossession.

Mots clés: Classe, immigration, études terre-neuviennes

$\sqrt{2}$ ort McMurray existed before the oil sands industry. It is not the result of a corporate takeover nor is it a classic company town. However, like all resource towns, it exists because of fixed, valued resources that multinational corporations want to commodify. Although it was a permanent settlement in the 1860s (as a Hudson's Bay Company storage post), the site of another attempt at resource development (salt mining in the 1920s), and an overnight stop en route to the Yukon gold rush, Fort McMurray remained a remote outpost of under one thousand people until the construction of the Great Canadian Oil Sands Company in the 1960s (Huberman 2001). Following two successive booms and the mushrooming of multinational investment in the oil sands, its population is now part of the global flows of capital and people. In this context, the idea of community is attractive to big oil for the labour force stability it can provide. Attempts to create community amid complex class relations are now part of a place that was once made up of seasonal trappers, barge workers, small businesses, and - ubiquitous in remote resource towns of Canada - the Hudson's Bay Company.

In 2011, the Regional Municipality of Wood Buffalo (RMWB), headquartered in the large urban service area of Fort McMurray, launched "What's the Big Idea?" a public consultation phase of the Municipal Development Plan (MDP). It included open-house charettes and, over 
a six week period, invited commentary via web-based questions such as "What are your big ideas to make our region a leader in sustainable development?"; "Do you feel safe in your community; why or why not?"; "Are all the services you need available in Wood Buffalo? If not, what's missing?"; and "What makes your community feel like home?" The MDP, a twenty-year guiding document approved on 25 October 2011, included over 11,000 "conversations" (www.bigideawoodbuffalo.ca/) that were more a list of one-off comments than a back-and-forth dialogue. This was a fairly typical online comment:

Wood Buffalo is filled with people who have a genuine sense of community. So many of us are from places far from here, and it is through community groups and the efforts of the RM that we are finding this a great place to live. I would love to see improvements to the public transit system and a much-needed improvement to shoveling public sidewalks in and around town. Not everyone drives! I hope that the MDP helps Wood Buffalo become a welcoming and functioning community for ALL. (17 March 2011)

A less typical and much shorter comment, printed on a post-it note at a Big Idea open house, stated: "Encourage community living rather than community working" (16 March 2011).

The MDP process is informed by aspirational citizenship (Raco 2009): if your voice is not heard or you are not reflected, it is because you did not stand up and have your (virtual) say, and did not choose to be engaged in projects spearheaded by institutions such as municipalities (Wilson 2004). In this mode, as Creed (2006a, citing the work of Nikolas Rose) argues, community functions as both the language of being selfgoverned and the spatial container - such as a city - of self-governing behaviour. Tethered to the oil industry, the municipality uses a Habermasian legitimation crisis intervention: it uses itself, an already existing institution (Bell and York 2010), to promote community. A "genuine sense of community" is not clarified, nor does it need to be, because ultimately, community is whatever Big Idea individuals want it to be.

De Genova (2005) argues that community is the "conjuncture of social relations"; it is composed of numerous places, and is established through the everyday social interactions and practices of various migrating groups, capitalist ventures, and the nation-state. Community is thus open to multiple interpretations: the municipality can exert itself as a central scale in that process, while sometimes, contradictorily, (virtual) action can be assumed to be community (Herbert 2005). De Genova's definition also allows for an examination of the tensions that exist between community as an idea and community in practice, as illustrated by 
initiatives such as Big Idea. As elsewhere, economic and political forces have reordered historical, spatial, and social relations in Fort McMurray to the extent that "community" is not so much a definable "thing" as it is a constant challenge that perhaps never really materializes. As Carbonella (2005) argues, specific claims to community are always tied to larger political and economic forces, and as a result are often fraught with contradictions. Simultaneously, complex class relations, obscured by assumptions of a unified community, must be maintained to ensure the stable population of workers required by the oil industry. Precariousness and risk aversion thrust residents into something seemingly unified: "community by necessity" keeps some people in place (literally and metaphorically). Community is a hegemonic label that fetishizes this struggle for security, a placeholder for whatever it needs to be in any given historical moment, and thus seldom poses challenges to capitalist accumulation processes.

The narrative that "Fort McMurray is [good paying] jobs" — the median annual wage in 2005 was $\$ 124,592$ (Statistics Canada 2006) and by 2010 was nearly $\$ 170,000$ (Statistics Canada 2012) — suggests that community is household financial security. This narrative obscures the pervasive insecurity that comes with engaging in commodified labour, an insecurity particularly evident since the neoliberal turn and subsequent withdrawal of the state from, for instance, providing the social services that made up a social wage. Fort McMurray attracts people from across Canada and the globe. However, the usual markers of household wellbeing and stratification, such as education and income, are less meaningful in Fort McMurray, where university educated engineers might earn less than mine workers with grade twelve educations such as welders and heavy equipment operators. Professional work is not subject to overtime whereas site workers can often pick up additional shifts (sometimes grossing close to $\$ 1,000$ per 12 -hour shift). Creed (2006b) argues that community is a way of calling class out but not naming it as such. Because the most obvious indicator of class - economic status - is skewed in Fort McMurray, it is necessary to look deeper into those forces that have shaped and continue to shape this "community by necessity."

In this paper, we discuss the experiences of two groups and how they do or do not experience community. We discuss Newfoundlanders who migrated west to work in the mines and who have lived and worked in the area since the 1970s and 1980s. We then turn to immigrant professionals educated overseas who came to Fort McMurray during the boom of the early 21 st century; some were recruited by industry, others not. We examine the interpretations of community as exercised by Newfoundlanders and immigrants (non-Canadian born migrants), focusing 
on those who have, for whatever amount of time, made Fort McMurray home. We argue that community is a mask for the precariousness of productive and social reproductive work in this context. The purpose of this paper is to illustrate how "community" as an idea and a discourse obscures cleavages that emerge from throwing diverse groups together into this container called Fort McMurray, how these cleavages work to the benefit of capital (Smith 1990; Harvey 2006), and how the contradictions of capital present themselves in the lives of working people as they struggle to shape meaningful spaces for themselves within the accumulation process.

\section{Community and Class: A Necessary Collision}

Community has long had a positive and desirable connotation. In the sociological tradition, it has been an idealized binary that opposes the pastoral connectivities and naturalized relationships of rural life (Gemeinschaft) to the abstraction and disengagement of urban Gesellschaft (Bauman 2001; Creed 2006a; Elliott 2010), i.e., a false opposition of urban industrial life replacing the pastoral community (Creed 2006b). Other interpretations have included: enough people in a place at a time to call themselves a community (Murphy 2007); the preoccupation with the maintenance of borders and boundaries (Creed 2006b), whether self-defined or state-established (De Genova 2005); a realm where governmentality is exercised as the advanced liberal state replaces the socialized welfare state (Rose 1996); and a thing to mobilize around, whether that be an immediate, defined crisis like the need for community policing (Herbert 2005) or a localized response to global challenges (Defilippis et al. 2010). Bauman (2001:100) argues that community most strongly manifests when "collective existence is threatened." In postmodern framings of intersectional identity formation, community may be an entity hyphenated by ethnicity, nationality, sexuality, and so on. In their examination of coal mining in West Virginia, Bell and York (2010) make reference to "economic community identity," whereby residents of a place identify as a community because they/it are subject to accumulation processes that are beyond them.

The resilience literature takes a different tack by focusing on how public engagement enables reflexive responses to challenges (environmental, economic, and other crises or disasters) and is fostered through kinship, place-based affinity, or thick social capital (Murphy 2007; Lombardi et al. 2011). This suggests that community determines what kind of response is possible (Middlemiss 2011) and defines the local normatives 
of what a responsive community looks like and should be. In this way, the resilience approach to community has some affinity with the concept of social reproduction. Typically described as undervalued, noncommodified, feminized labour performed in and for the household, social reproduction refers to the processes that reproduce workers from day to day and from generation to generation (see, among others, McDowell 1999; Luxton and Corman 2001; Armstrong and Laxer 2006); it is associated in common sense terms with the "private" realm (Mitchell et al. 2001). While social reproductive activities usually rely on kinship and place-based affinity or social capital, they certainly do not take place only behind closed doors. Indeed, in this paper we assume that the networks and connections that make social life possible are not unlike how community ends up being defined by the people living it.

Community is intertwined with social reproduction and production. By producing a seemingly naturalized world of belonging, community acts as the "logic" that enables production and social reproduction, which in turn enables waged labour. Thus, community is contradictory in that it is considered "natural," shared, and homogeneous even as those very claims are precarious and conflict-ridden. In an historical era when "inside" and "outside" do not hold, argues Bauman (2001), unity needs to be made:

Common understanding can be only an achievement, attained (if at all) at the end of a long and tortuous labour of argument and persuasion and in strenuous competition with an indefinite number of other potentialities - all vying for attention and each promising a better (more correct, more effective or more pleasurable) assortment of life tasks and solutions for life problems. (2001:14)

Over time, then, community is achieved by constantly being reworked: subject to doubt, then reinterpretation, maintained only through active maintenance, repetition of its meaning, and vigilance in response to attacks from the outside. In the socially concerned welfare state, sameness in the accessing of rights, work, and social services is to be achieved through state redistribution projects, giving the social ("an order of collective being and collective responsibilities and obligations") precedence over community (Rose 1996:333). As state redistribution diminishes, the local scale does not usurp the state or stop being subject to government, but regionalism, community, and identity emerge as increasingly important in defining what can be acted upon and in what ways (Painter 2002; for specific examples, see, among others, Larner 2002; Larner and Laurie 2010; McDowell 2003). Included in this is the struggle over what community can or should mean. Capitalism shapes class relations and 
thus what community can and does look like - a process and a struggle that are especially pronounced in resource communities (Dunk 2002).

Although modern capitalism moves inconsistently and gives rise to different materialities, capital must continually expand across geographical space in order to maximize accumulation but at the same time remain fixed in place to make this expansion possible (Smith 1990). To overcome this contradiction, labour power must also be fixed and mobile: free to follow capital wherever it settles at any given time and place, and then brought into a fixed relationship as needed. Initiatives such as Big Idea attempt to create a unitary community to facilitate this process as well as to ameliorate issues that inevitably arise when diverse groups of people with often competing interests are thrown together.

Community is a space that in effect elides class differentiation. As Wolf explains, as capital moves across the globe it must always search for new ways to accumulate and in the process it creates new working classes. These new labouring classes find themselves situated within changing political economic hierarchies even as they change, and are changed by, their very presence in those hierarchies (Wolf 1997 [1982]:379-383). Moreover, as capital and labour meet, labour is ranked according to its usefulness in a particular sector of a market and workers are ranked against each other. This distribution of capital and markets with the consequent division of labour across local, regional, national, and international lines is always changing. The features of specific working classes are therefore highly variable. They come from different geographic locations and differ in the way they enter the labour market, both of which may influence access to resources and have a distinct bearing on job recruitment. Scholars of identity politics have attempted to address the various ties that bind mobile and diasporic populations, often by downplaying class relations in favour of exploring the political aspects of subordinated groups who struggle to maintain ethnic or cultural difference in receiving locales. The declaration and celebration of difference, however, necessarily involves the exclusion of other groups and can lead to intragroup conflict. This tension is a result of fluid class relations that must be understood as historically situated, spatially constructed, and necessary for capital.

The general tendency of capitalism is to

create a 'disposable mass' of laborers out of diverse populations, and to then throw that mass into the breach to meet the changing needs of capital ... [recreating] the basic relation between capital and labor power. (Wolf 1997 [1982]:380) 
Despite the homogenizing tendencies of capital (Smith 1990), what emerges from the breach is a great heterogeneity that is historically and geographically specific, and varies over time and across space. "Community," therefore, doesn't just happen spontaneously; specific claims to community are always tied to larger political and economic forces, and as a result are often fraught with contradictions (Carbonella 2005). The potential to collectively build community within that breach poses a challenge because those higher up in the labour hierarchy can advance their own claims to community more forcefully than those at the bottom. This ongoing making and remaking of social relations reinforces/recreates the production of difference, which is integral to the accumulation process.

Community is organization - spatial, social, political. It may provide identity (Creed 2006b), but in the contemporary moment, it fetishizes individual self-maximizing, collective risk aversion in the absence of the state, and one's aspirational citizenship (Herbert 2005; Raco 2009). We argue this is why class looks flattened or muted. In Fort McMurray we have a reified social relation that is the outcome of a distinctive process of place formation predicated on how labour needs to behave:

the unequal social relations through which global capital, nation-states, and transnational labor, together in the contradictions of struggle, unevenly produce the particular localities where 'globalization' takes place. (De Genova, quoted in Harvey 2009:268-269).

This demands an in situ reading of the methods and means of risk avoidance, of how community is fetishized "by necessity," in a particular place and time, all while not interfering and perhaps even aiding with capitalist accumulation.

\section{Methods}

The period that we capture in our research was seen by many McMurrayites as a reprieve from the boom. The financial crisis of 2008 meant worker layoffs, fewer contractors in camps outside of town, and fewer winter-time exploratory workers. These changes were felt in the city of Fort McMurray as less traffic, increased access to community resources, and better selection in the stores. The very nature of boomtowns means that our research captures a moment in time and space, but that the moment becomes part of the future - a future that, despite our desire to do so, we have not been able to keep up with since leaving the field. 
Both authors did extensive fieldwork in Fort McMurray. Tracy Winters, a social anthropologist, studies capitalist productions of space and labour migrants' negotiations of and contribution to the shaping of those spaces. With a broad theoretical underpinning informed by Marxist geography and critical labour history, and geared toward an anthropology of labour, she spent approximately twelve months in the oil sands region as an active participant in the daily lives of a small group of Newfoundlanders, most of whom had come to Fort McMurray between 1977 and 1985. Participant observation and unstructured interviews were carried out between October 2009 and September 2010. Claire Major, a social geographer who lived in Fort McMurray for sixteen months from 2009-2011, studies class and the social reproduction of labour in and for the oil sands, and, more generally, the city as a scale of social reproduction. Knowing that Fort McMurray has been subject to "drive-by journalism" for nearly a decade now, her approach was to spend extended time getting to know Fort McMurray. Using a phenomenological process of watching place unfold (to a reflexive and not unbiased self) over this time frame guarded against imposing a research agenda beyond the initial broad research topic. Initial interviews resulted from directly contacting social service providers and municipal departments, from which further interview subjects followed through snowball sampling. She also posted requests for research participants in public places and on social media sites.

Although in passing people are willing to comment and/or complain about industry and the nature of extractive work, it was difficult to establish trust in the research context (perhaps due to the fear of job loss if negative comments got back to the employer). Hence, each of us relied on a small group of individuals with whom we became close. From them we gathered information about the oil industry, experiences of working on site, and hopes, expectations, and disappointments about Fort McMurray or the process of migration.

This paper draws on interviews and participant observation with six Canadian-born, high-school educated mine labourers and tradespeople from Newfoundland and five immigrants who are primarily universityeducated professionals. While the commentary and vignettes below did not emerge from direct questioning about "community," they point to the complex masking work that community accomplishes in Fort McMurray, especially when the experiences of the two populations in the hierarchy of labour are considered side by side. The names of our informants are pseudonyms and we have made all efforts possible to conceal their identities, which is particularly challenging in an isolated place 
where, especially among site workers, networks may not be particularly deep but are far-reaching.

\section{Community by Necessity}

In this section, we explore the demands of oil capital's waged labour on the life cycle of workers (as is illustrated in the case of Newfoundlanders), and on the willingness of workers to insert themselves into the labour hierarchy (as found in the case of immigrants). We feel it is important to point out that not everyone's experience of "community by necessity" is negative, given that there is often quite a lot of pride associated with being a McMurrayite. However, we theorize that community is more critical to overall social reproduction than it is to an idealized place to raise the kids, for instance. Despite the variation in the background of the workers and residents who participated in the study, our two separate cases come to very nearly the same conclusion: the notion of community hides much more than it reveals. Participation in the flattening of class, in community, in risk avoidance, is motivated by material reproduction and survival (housing, a bed) along with something more idealized (the future, opportunity).

\section{Fort McMurray, Second Largest City in Newfoundland}

Cooper (1987:276) argues that alliances and conflict arise within classes but also cut across class lines. Historical specificity is therefore necessary to examine how class interests merge or diverge, and to what degree, in a given circumstance. While it is impractical to recount the entire history of the oil sands region here, it is important to note that it encompasses waves of migration from many parts of the world - Lebanon, the Phillipines, Venezuela, Ethiopia, China, and Somalia to name a few. One of the earliest migrations was from within Canada, but like later migrations, it came during a period of capital restructuring.

Prior to 1949 , the migration pattern of rural Newfoundlanders was largely seasonal and regional. Once the hub of a transatlantic fishery, Newfoundland has long been integrated into the global economy, but the monetary system that existed there - truck, a form of credit - provided inshore fishers somewhat of a buffer from fluctuating markets. That all changed after World War II, as Premier Joseph Smallwood led Newfoundland and Labrador into Confederation determined to industrialize the land-based economy and "modernize" the fishery. He promised to free rural Newfoundlanders from the salt fishery, which was, in his view, an outmoded way of life and the reason for Newfoundland's "backward- 
ness" (Cadigan 2009; Bishop-Sterling and Webb 2008). Over the course of three separate resettlement programs designed to move labour to established "growth centres," more than 28,000 people were displaced (Maritime History Archive 2005). Resettled people were promised jobs. Instead, they got a drastic change in the way they could create a livelihood for themselves. While some rural people voluntarily moved to locales where they had friends and relatives, others found themselves isolated socially and economically (Wright 2003:100). Many people ended up on government assistance programs. Others simply left.

Then, the unthinkable happened. Smallwood's quest to modernize the fishery eventually led to the declaration of an indefinite moratorium on the cod fishery in 1992. This effectively ended an industry that was over five hundred years in the making. By 2001, rural communities had lost upwards of 50,000 people to outmigration (Steele et al. 1992; Higgins 2008). Newfoundland and Labrador's greatest export had become its labour.

Many initially made their way to industrial areas of Ontario; others were recruited directly by Syncrude and Suncor in the early development of what was then called the tar sands (1960s-70s). More recent migrants have followed the money, bypassing Ontario altogether in favour of Alberta. They come to Fort McMurray to work, both on a temporary and permanent basis. Many of the people who reside here initially came to make their fortunes and had every intention of returning home. They tagged along with a friend or relative who had a job, or came alone; thirty years later, many are still here. During the last boom, some came on a "two and out" plan. Others came on the five-year plan. Many of those people are still here. Still others came, left, and came back again. Some brought their families. Some work here and live elsewhere. Many work upwards of sixteen hours a day, leaving little time for a social life outside of the workplace. To say that Fort McMurray is a community in flux would be an understatement.

For example, Rick, from rural Newfoundland, migrated in 1978. When asked why so many Newfoundlanders came in 1978 and 1979, he said that everything was shutting down back home. He said that many were recruited from a Labrador company that was experiencing financial hardship at the time. According to him, Syncrude tried to hire Albertans but could not find enough workers willing to come, so they went to places like Newfoundland to find them. Rick says most Newfoundlanders want to work, and do not want "stamps"; any job would do, so they came en masse. He is retired now and has no plans to return to Newfoundland because his grandchildren live in Alberta. He does not know how long he will be able to stay here, though. Due to extenuating circumstances, his 
pension was withheld for months. Living on his savings in the interim, he laments that his nest egg cannot be replaced. Suffering from a variety of ailments, he can no longer work. He acknowledges that his pension is large by Canadian standards, but it is tough to get by on it in Fort McMurray with its high cost of living.

Paul is in a similar situation. In the late 1970s, he also had to leave Newfoundland and head west. After putting in many "years of service" to Syncrude, he had a heart attack at work. He is now on permanent disability and is no longer permitted on site. His grandchildren live in western Canada so he has no immediate plans to return to Newfoundland. His pension is enough to survive on because of the municipal subsidized housing program, but should his rent increase, he will no longer be able to live in Fort McMurray. He is still not sure if he wants to be there.

Louis left for Fort McMurray during the same period. Recruited by Syncrude, his starting wage thirty years ago was $\$ 7.82$ an hour. He says that back then, Albertans would not relocate for such dirty jobs. When the price of oil went up, however, these suddenly became "good jobs." When the next recession hit, then-mayor of Calgary Ralph Klein told the eastern "bums" and "creeps" looking for work to go home. Louis took great exception to this and to the notion that Syncrude built Fort McMurray, proclaiming that Newfoundlanders built this place. Yet, after more than thirty years Louis and his wife packed up and left for Arizona just days after retiring from Syncrude.

Pete came more recently. In Newfoundland, he attended trade school, hoping to secure stable employment. He couldn't find anyone willing to take him on as an apprentice so he had to leave. One of his first jobs on site was operating heavy equipment, but he has since moved on and up the ladder. He has been with Syncrude for several years. He says that although he started late, he will still have an "okay" retirement fund if he can maintain his job. He worries about that though, stating it was a good place to work until about ten years ago, when Exxon "took over" Syncrude's rotating system of management. He feels that working conditions have gone downhill since then. Prior to this, they only had one fatality that he could remember; they have had three fatalities in the past three years. He worries about his employer's recent restructuring of the retirement plan, which penalizes you for retiring early. He wonders just how secure his job is, because "the Americans" keep bringing in "key" people. He says that he does not trust anybody; he hates this town so does not spend much time here. He hangs out with the few he does trust (namely Rick and Louis, prior to Louis leaving). During the course of this conversation, someone called to tell him that a coworker had a heart 
attack at work and died in hospital two days later, one year short of his retirement. Heart attacks do not count as worker fatalities.

The assumption of community implies a certain degree of rootedness to a particular place. The above vignettes illustrate that the geography of capital as it has played out in Fort McMurray has made it very difficult, if not impossible, for this group of workers from Newfoundland to actively engage in the place-making process. Never sure exactly how long they will be here, they have invested very little of their time in communitybuilding efforts. This landscape of uncertainty has been shaped largely by forces beyond their immediate control, and is crisscrossed by issues of ownership, extraction of surplus value, and immediate and long-term job security.

Corporate profits have skyrocketed in the oil sands and in the energy sector as a whole. Economist Jim Stanford (2011) calculated that in 2010, top corporations in the resource sector - Suncor, Imperial, Athabasca Oil Sands, and CNRL among them - made approximately $\$ 325,000$ from the labours of each worker in the sector overall (which includes but is not limited to petroleum). Yet in Fort McMurray, workers did not outwardly express concern about the massive profits the oil industry makes from their labour, nor did they verbalize the degree of control that these companies have over their lives, whether they were unionized or not. Syncrude, historically the largest single employer of Newfoundlanders, is not unionized.

In his study of ARAMCO, Vitalis (2007) suggests that when US energy giants moved into new territories they brought with them attitudes and labour practices from home. Syncrude is 25 percent owned by Imperial and currently managed by Exxon, Imperial's parent company. Its predecessor, Standard Oil, spent many years fending off unionization, assisted in part by former Prime Minister MacKenzie King (Grant 1998; Patmore 2006; Rees 2010). After at least two attempts in the late 1970s, Syncrude employees are still not unionized. None of Winters' contacts that worked there at the time signed a union card, afraid that if they did, Syncrude would leave and they would lose their jobs. Despite worrying about job security, most do not believe that Syncrude needs a union because they get raises when neighbouring (unionized) Suncor employees are in bargaining.

While this points to a larger question about the nature of unions and their ability to build solidarity in heavily industrialized landscapes, unionized workers in Fort McMurray appear to earn higher wages. However, this is not a guarantee of protection. For example, Thomas recounts his version of the layoff of a coworker who challenged working condi- 
tions and discusses why more Newfoundland labourers do not offer such challenges:

While we're up there [working in the oil sands], we're pretty well at the mercy of everybody up there. ['Adam'] didn't take that lying down, and unfortunately, I wish he would have maybe handled it in a different way, no, but he went right out there. Man, they zeroed in on him ... then the next thing I heard was that [he] was laid off, and I really admire him, and I stand up for him on a daily basis there, and I tried to, like, discussions in the lunchroom and that there, like, they said well you know ... he shoulda kept his mouth shut ... shoulda and I mean if nobody speaks up, nobody gets hurt, you know ... for a guy like him to stand up and to lose his job like that, and then look what the union did, they just folded, they collapsed, eh.

... I talked to a lot of these Newfoundlanders ... I don't know ... who's makin' all the money out here? On the backs of the bloody labourers ... I mean, how many times have I talked to guys there, they're all bloody afraid to speak their mind because they've got too many commitments.

Indeed, another participant, Vic, claims that there is a real politics of fear here. He believes that behind recourse to "community" there is a darker side that slips by unnoticed. It becomes very easy to forget what is happening just a few kilometers north of town, until someone is hit with yet another health problem, or someone else is fired or killed at work.

These silences are revealing in that the ongoing struggles against dispossession - the precariousness that draws these people together in the first place - have ensured the reproduction of a relatively docile workforce. In addition, the landscape of Fort McMurray as a "working man's town" makes it more or less a stopover on the way to somewhere else, and ensures that even if you wanted to stay, it is an expensive place to retire once your wage labouring years have expired.

Few of Winters' contacts talked "community," perhaps for good reason. While Newfoundlanders, particularly those who came in the first wave of migration, are viewed by many other migrants as "insiders" (i.e., you cannot get a job in Fort McMurray if you are not from or do not know a Newfoundlander), a number of factors have left these people vulnerable and unsettled in specific ways. Lower levels of education and mounting levels of household debt have assured a captive workforce, making it impractical if not impossible for most to return to a place where wages in most sectors are and always have been much lower, and where loved ones have died or also moved "out west," providing little incentive to "go home"; the power of organized labour has been weakened by company-friendly unions such as Christian Labour Association of 
Canada; the federal government has been determined to strip organized labour of many hard-fought benefits that have also benefitted nonunionized work places; already weak labour laws in Alberta have generally favoured the employer; the rapid expansion of the Temporary Foreign Worker Program contributes to depressing wages over the long term and further increases the levels of short-term contract work; and a dizzying array of shift schedules and work hours make it difficult to connect with friends and neighbours.

Meanwhile, some of these long-timers argue that fly-in, fly-out workers are a scourge, contributing nothing to Fort McMurray - a complaint that echoes, ironically, the animosity that many Albertans expressed toward Newfoundlanders in an earlier moment of the boom when the price of oil shot up and digging in the bitumen suddenly became lucrative. Some folks complain that "the Somalians" are taking all the jobs. Those in question, however, are not exclusively Somali, nor are they taking all the jobs. Hailing from various parts of Africa and possessing various skill levels, it seems that a number of these workers have been tracked largely into the lower wage transportation sector, driving oil workers to and from site and providing taxi service. They came for the same reasons that Newfoundlanders did: work. The movement of capital from one location to another has ensured the mobility of workers from places like Newfoundland and parts of Africa, and this process of inclusion/exclusion has a remarkable degree of continuity in the struggle against dispossession. Such continuity does not mark "community." Community as claim for Newfoundlanders is every bit as tenuous as it is for some other long-term (if not necessarily permanent) residents of Fort McMurray for the reasons stated above, and perhaps even more so. Many cannot afford to leave, but these same people are always on uneven footing, never knowing if and when they will be shown the gate (fired), replaced by a contract or temporary foreign worker, or even killed on the job. Some stay longer than others, but few have put down permanent roots precisely because of these uncertainties.

\section{Immigrants: "Good Jobs," Celebrating Difference}

In 2006, foreign-born immigrants made up 11 percent of the population of Fort McMurray. It is the third most diverse city in Alberta, and ranks sixteenth nationally. While some non-Canadian born McMurrayites have lived in the city for more than thirty years, recent migration is significant: by percentile, Fort McMurray had the tenth highest population of immigrants arriving between 2001-2006 in Canada (Statistics Canada 2006). 
The immigrant population of Fort McMurray, which does not include the thousands of people in the Temporary Foreign Worker Program, is largely composed of two groups. There are professional newcomers directly recruited by industry (from Australia, Saudi Arabia, Venezuela, South Africa) into engineering, mine operations, or mine management. Among these newcomers, it is usually the male breadwinner's education and experience that provides the opportunity for the family to migrate. Their first place of settlement in Canada is Fort McMurray. The other major group comprises secondary migrants who move to escape the "survival jobs" - shelf stocking at Walmart, sporadic factory work - of gateway cities (often the Greater Toronto Area). Some of them are skilled professionals unable to secure work in their field elsewhere in Canada and who find jobs in the mines (engineering, chemistry, accounting and purchasing, quality assurance) or in professional positions in town. Others among them are less skilled, possibly refugees, and typically single men who might have a family elsewhere in the country, such as in Edmonton or Toronto. They take what work is available: cleaning offices, cleaning hotels, or driving cabs. Graduating to driving bus for companies that ferry workers to site, or for the municipality, is considered a step up in employment, as it pays well relative to elsewhere in Canada even if it is locally equivalent to a living wage.

Community is a lived concept that derives meaning in part because it enables social reproduction to happen. When recruited professional workers arrive in Fort McMurray they are typically given three months of housing while they shop for a house to buy, are driven around town and shown resources (schools, recreation centres, grocery stores), and given advice about daily living. This suggests a paternalistic employeremployee relationship, a place of care and welcome that actively supports social reproductive activity. At the other extreme are the secondary migrant workers. Staff at homeless shelters comment that Somali men who are newcomers to Fort McMurray sometimes spend a night or two in a shelter before they find contacts and a place to stay with other Somalis. The cost of rent means their families are elsewhere, as many immigrant single men share rooms or basements at rental rates of about $\$ 800$ per month (the bottom-end rental rate). It further entrenches precariousness and reproduces a class of devalued workers - material conditions are manifested as class (Edwards 2000), and masked through community.

Syed, an immigrant resident in Fort McMurray for several decades who holds a professional job on site, says, "We have very strong employers that keep this Fort McMurray. They're basically the bloodline of it." He suggests that what makes Fort McMurray a livable place is the oil industry. In this way, community derives its power from the promise 
of opportunity that pervades Fort McMurray, masking difference and uncertainty. Mike, an immigrant in his 40 s who works with secondary migrants with few marketable skills, says the 2008 economic slowdown meant "I saw a lot of immigrants without a job living with someone. Maybe part-time work at McDonalds but they are hopeful for tomorrow so stay in Fort McMurray." But as Dorow and Dogu (2011) found, the placement of hope differs, depending on one's job or history. For longtime residents of Fort McMurray, hope is "embedded in and for the community" (2011:273), and springs from the opportunities offered by the oil industry. This same hope might be experienced by newcomers with marketable skills (namely engineering, accounting, finance, purchasing, or quality assurance for heavy industry); professional jobs in industry allow a continuity of association with place, with wellbeing, with achieving one's goals for family. Others, however, "are lucky if they get into an oil company," as Mike puts it. Syed, says, "I'm pretty sure these immigrants or folks who are trying to get into these work environments would be willing to settle for less than the market rate so they can get started."

A good job is not only subject to individual interpretation but also predicated on whether or not the local labour market is absorbing what is otherwise the latent labour of deskilled workers (at a discount). Thus, a "good job" is perhaps, says Syed, "flipping burgers and making \$18 an hour." Such workers are unlikely to access well-paid site jobs and thus to transcend their cramped basement apartments, languishing in jobs that pay remarkably well - but that look remarkably the same - relative to work they could get elsewhere in the country. At best they may be employed on site working for contract firms, serving as the deskilled workforce of advanced capitalism that does the cleaning and other less desirable tasks that always need to be done (Major 2008). Thus there is heterogeneity in the immigrant experiences that are motivated by hope, with the outcome inevitably being "good" despite some finding work on site, others finding work in the fast food industry. Hope trumps class relations. That is, class (where one fits in selling one's labour) becomes less important than having one's hope vindicated. Transcending the monotony of the service sector is less possible than becoming part of the big picture that oil companies orchestrate.

More than this, the labour structures of the oil industry homogenize and thus help to directly create each of these groups as "natural" communities, to make "the Somali community" and "the Venezuelan community" distinctive and unitary entities. This has the effect, in turn, of flattening and obscuring the differences between groups within the labour hierarchy - for instance, that one group has little in the way of formal education or skills and migrates to Fort McMurray in a game of chance, 
while the other is recruited from a transnational professional class. This material conditioning of community is echoed in the celebratory multicultural narrative of immigrants; they are, in part, what makes Fort McMurray livable, but they are often interpolated in the social landscape through apolitical interpretations of inclusion. Hameed (a recent migrant to Fort McMurray, who came on a short-term contract; he is an immigrant who lived in eastern Canada for more than 20 years) is a bridge-builder between ethnic and other identity-based communities and the Canadian born population. His ideal is a "healthy community, which will benefit the town in the end." This idealized, altruistic refrain is echoed by community boosters, whether they are the free agent he is, bloggers who extol the benefits of living in Fort McMurray, or the city, community college, and industry working together to rebrand it. The existence of difference is part of this rebranding, perhaps not verbalized as such, but strategic, whether it comes from the ground up (via ethnic or multicultural organizations) or middle down (via the municipality and campaigns like Big Idea).

Indeed, there is room for celebration, and thus room for more contradiction. Irene, from India, is the wife of an engineer, a professional in her early 40 s who says that although having a child play hockey is what you need to do

if you really want to get into the Canadian system.... I have not seen a single Indian child taking part in that. And I'm very surprised that people don't go into recreational activities in which their [ethnic] community is not involved.

What to Irene is just an imagined barrier is for many people no barrier at all: comments like "in Fort McMurray, a Filipina nanny has the chance to befriend a Mexican cook" are not unusual. Such celebration fetishizes socioeconomic differences among newcomers (whether that is single male workers, nannies, others on temporary work permits, or professional couples). Thus, community creates a local politics (Herbert 2005): a politics where politics are not necessary.

The cultural flattening of class difference contributes to the broader idea of unity, of the maintenance of something over time, that is so inherent to imagining community - a commonsensical response to the need for both highly skilled migrant labour and migrants who can be deskilled, whether that is for oil companies or in the notoriously understaffed service sector in town. Immigrants participate in the celebratory narrative, perhaps to reinforce for themselves that labour migration predicated on taking a temporary work contract, moving without one's family, taking the lowest paid work in Fort McMurray to be a live in caregiver, and/or uprooting one's entire family — was a good decision. 
In Fort McMurray, this unity and continuity also fixes to place; required and appreciated by the oil industry, people fix themselves, permanently or temporarily, to the resource in the ground. Through this combination of fixity, unity, and continuity, "community" helps to accomplish the implication of security (in the reproduction of one's own household, whether or not they are in Fort McMurray) needed by the oil industry. Put another way, high wage, high labour demand in the oil industry means that workers across the spectrum "play it safe." Mine workers may remain mum about health and safety issues because their social reproduction is already so precarious. Well-educated immigrants also need some assurance of a job because they are far from home, in a place where the rules are different, at least until they have a chance to work elsewhere. Thus, some classes have more mobility than others, not just up and down the employment ladder but laterally in the ability to stay or leave. Many are treated as if they are especially useful and irreplaceable, which serves not only to attract labour to Fort McMurray and to make them stay, but also to mask the actual volatility and risk of working in an extractive industry. As Syed says, "If the oil price gets hit, a lot of these projects will either go on hold or will basically shrink down significantly. That will probably put more pressure on this community than anything else."

Ultimately, however, Fort McMurray cannot hold onto all newcomers, even if there are predictions of the oil sands industry needing to fill 52,000 jobs between 2012-2015 (Penty 2012). Yes, Fort McMurray is attractive to deskilled workers. It provides the chance to send money to their families elsewhere and the hope of a good life with a good paying job. It is attractive to newcomers with children in university, who maintain it as home because it offsets that financial burden. However, the recruited immigrant professional is part of a couple, often in their late $30 \mathrm{~s}$ or into their $40 \mathrm{~s}$; sometimes the male partner applies for a job within the company in which he already works - Shell, Suncor - and they relocate from Fort McMurray to Calgary. Spending a few years in northern Canada is an interesting adventure, an opportunity for their children to become fluent in English, but not a long-term project that they - from Caracas, Rio, Mumbai - care to embrace permanently. Others question their tenure because of concern about the future. Puja is from India, in her early 30 s, a professional awaiting Alberta accreditation of her vocation. She says that her future in Fort McMurray includes consideration of whether or not her children will be able "to study with good people around them," because for her, the Alberta school system is lacking in rigour. Another concern for the future has to do with industry's failure to commodify, for the oil industry, the skills of the wives of professional immigrant recruits who have difficulty accessing the local labour market 
because their particular skill sets do not meet local labour demands. We have met female math professors, software project managers, and health and safety health professionals who are unable to get work on site and who are frustrated by their own lack of career options and challenges. Community by necessity provides a partial, instrumental, and thus tenuous tether between people and place.

\section{Conclusion}

An examination of the tensions that exist between the idea of community and the lived experience of people illustrates that historically and spatially, economic and political forces have reordered social relations in Fort McMurray to the extent that "community" is not so much a definable thing as it is a constant challenge that perhaps never really materializes, neither for migrant Canadians nor for immigrants from abroad. Newfoundlanders rarely, if ever, use the word "community" despite the fact that for the most part they have been in Fort McMurray many years and are viewed by "outsiders" as "insiders." Immigrants and the nonprofit providers that work with them almost always mention community in interviews, and without prompting. From the excerpts herein of just five such interviews, interpretations of community include reference to: ethnicity; something that does not take care of people; audience; quality of life; latent labour forces; bridging differences; integration; an ideal to which people should aspire; not the image of Fort McMurray as just a place to work; a container for all subgroups; the right kind of behaviours; material representation of ideals; an identification of a place that is primarily about work; something that is challenging unless one has access to work; something tied to social services and the state/municipality; scale; and perceived barrier. And yet for both the Newfoundlanders and immigrants in Fort McMurray, identity is largely forged from one's relationship to production processes. These processes self-perpetuate, find spatial fixes, and engage workers from different geographies in different ways. Despite the variation in the background of the workers and residents mentioned herein, our two separate cases come to very nearly the same conclusion: the notion of community hides much more than it reveals.

Our findings complement Wolf's observation that diverse populations are lumped together, expected to assist capital in meeting its next demand, and then challenged to deal with the internal, localized logics of mitigation that arise. Some groups become constructed into "the problem" and thus contribute to the logic of community production, whether it is Newfoundlanders who simply would not go home in the recession 
of the 1980s, or the more recent assumptions made about Somalis in town, who are all too easily described as the reason for the drug trade and increases in violence. When "community" becomes accepted de facto, difference is enfolded into it, and those at both the top and the bottom of the labour hierarchy are able to claim community with ease, via their own commodification.

In short, community as idea provides a one-dimensional narrative that manages to engage multiple scales and a diverse population (and indeed depends on it), but it also masks shifting relations of production. As DeFilippis et al. (2010) suggest, it lacks the methods and means of challenging or changing economic or social injustice. Indeed, we suggest that in Fort McMurray, the production of community fosters security through the opportunity of work, and in this way discourages broad political engagement. The kind of everyday community that just "happens" - someone to feed the cat when you are out of town, to get rides from if you do not have a car (Herbert 2005) - further enables life to continue fairly uninterrupted. Throughout we have pointed to practices of risk aversion, the needs of particular groups to do so, and the ongoing struggles against dispossession that working people experience (i.e., job loss, pension cuts, risk of injury or death, newer groups coming in and "taking over," contract work, potential downward pressure on wages from increasing numbers of temporary workers).

"Community by necessity" is the social manifestation of risk aversion, legitimated through meso-level institutions like the municipality and campaigns like Big Idea. The urban is a more important site of social intervention than when the state was redistributive; indeed, "cities are at the interface of key processes of citizenship-building and community (dis)engagement" (Middlemiss 2011:440). Big Idea affords the kind of tokenistic opportunity that characterizes so much of urban planning, where engagement is invited for something for which the outcome is already largely determined (Flyvbjerg 1998). Worker-residents are engaged in the neoliberal rubric of aspirational selfhood as participants of both commodified labour relations and community, while not necessarily viewing themselves as being in either. Such is the contradiction of community, that it elides changing class relations, attempting to foster homogeneity through the rhetoric of shared opportunity and security, even while celebrating heterogeneity, the unintended consequence of the accumulation process. 


\section{REFERENCES}

Armstrong, Pat and Kate Laxer. 2006. Precarious work, privatization, and the health-care industry: The case of ancillary workers. Pp. 114-138 in Leah Vosko, ed., Precarious Employment: Understanding Labour Market Insecurity in Canada. Montreal and Kingston: McGill-Queen's University Press.

Bauman, Zygmunt. 2001. Community: Seeing Safety in an Insecure World. Cambridge: Polity.

Bishop-Sterling, T. and J. Webb. 2008. The twentieth century. In A Short History of Newfoundland and Labrador. Newfoundland Historical Society. Portugal Cove-St. Philips: Boulder Publications.

Bell, Shannon Elizabeth and Richard York. 2010. Community economic identity: The coal industry and ideology construction in West Virginia. Rural Sociology 75(1):111-143.

Cadigan, S.T. 2009. Newfoundland and Labrador: A History. Toronto: University of Toronto Press.

Carbonella, August. 2005. Beyond the limits of the visible world: Remapping historical anthropology. In Don Kalb and Herman Tak, eds., Critical Junctions: Anthropology and History Beyond the Cultural Turn. New York: Berghahn Books.

Cooper, Frederick. 1987. On the African Waterfront: Urban Disorder and the Transformation of Work in Colonial Mombasa. New Haven, CT: Yale University Press.

Creed, Gerald W. 2006a. Reconsidering community. Pp. 3-22 in Gerald W. Creed, ed., The Seductions of Community. Santa Fe, NM: School of American Research Press.

2006b. Community as modern pastoral. Pp. 23-48 in Gerald W. Creed, ed., The Seductions of Community. Santa Fe, NM: School of American Research Press.

De Genova, Nicholas. 2005. Working the Boundaries: Race, Space, and Illegality in Mexican Chicago. Durham, NC: Duke University Press.

DeFilippis, James, Robert Fisher, and Eric Shragge. 2010. Contesting Community: The Limits and Potential of Local Organizing. Piscataway NJ: Rutgers University Press.

Dorow, Sara and Goze Dogu. 2011. The spatial distribution of hope in and beyond Fort McMurray. Pp. 271-292 in Tonya K. Davidson, Ondine Park, and Rob Shields, eds., Ecologies of Affect: Placing Nostalgia, Desire, and Hope. Waterloo, ON: Wilfred Laurier Press.

Dunk, Thomas. 2002. Remaking the working class: Experience, class consciousness, and the industrial adjustment process. American Ethnologist 29(4):878-900. 
Edwards, Paul. 2000. Late twentieth century workplace relations: Class struggle without classes. Pp. 141-164 in F. Devine, M. Savage, and J. Scott, eds., Renewing Class Analysis. Malden MA: Blackwell.

Elliott, Brian. 2010. Constructing Community: Configurations of the Social in Contemporary Philosophy and Urbanism. Toronto: Rowman \& Littlefield.

Flyvbjerg, Bent. 1998. Rationality and Power. Chicago: The University of Chicago Press.

Grant, H.M. 1998. Solving the labour problem at Imperial Oil: Welfare capitalism in the Canadian petroleum industry. Labour/Le Travail 41(Spring):69-95.

Harvey, David. 2006. Spaces of Global Capitalism: Towards a Theory of Uneven Geographical Development. London: Verso. 2009. Cosmopolitanism and the Geographies of Freedom. New York: Columbia University Press.

Herbert, Steve. 2005. The trapdoor of community. Annals of the Association of American Geographers 95(4):850-865.

Higgins, Jenny. 2008. Rural depopulation. Accessed 29 August 2012 from http:// www.heritage.nf.ca/society/depopulation.html.

Huberman Irwin. 2001. The Place We Call Home. Fort McMurray, AB: City Centre Group, Inc.

Larner, Wendy. 2002. Globalization, governmentality and expertise: Creating a call centre labour force. Review of International Political Economy 9(4):650-674.

Larner, Wendy and Nina Laurie. 2010. Travelling technocrats, embodied knowledges: Globalising privatisation in telecoms and water. Geoforum 41:218-226.

Lombardi Rachel, Libby Porter, Austin Barber, and Chris D.F. Rogers. 2011. Conceptualising sustainability in UK urban regeneration: A discursive formation. Urban Studies 48(2):273-296.

Luxton, Meg and June Corman. 2001. Getting By in Hard Times: Gendered Labour at Home and on the Job. Toronto: University of Toronto Press.

Major, Claire. 2008. Affect work and infected bodies: Biosecurity in an age of emerging infectious disease. Environment and Planning A 40(7):16331646.

Maritime History Archive. 2005. "No great future": Government sponsored resettlement in Newfoundland and Labrador since confederation. Accessed 20 October 2009 from http://www.mun.ca/mha/resettlement/rs intro. php.

McDowell, Linda. 1999. Gender, Identity and Place: Understanding Feminist Geographies. Minneapolis, MN: University of Minnesota Press. 
McDowell, L. 2003. Masculine identities and low paid work: Young men in urban labour markers. International Journal of Urban and Regional Research 27(4):828-848.

Middlemiss, Lucie. 2011. The effects of community-based action for sustainability on participants' lifestyles. Local Environment 16(3):265-280.

Mitchell, K., S. Marston, and C. Katz. 2001. Life's work: A review and critique. Antipode 35:415-442.

Murphy, Brenda L. 2007. Locating social capital in resilient community-level emergency management. Natural Hazards 41:297-315.

Painter Joe. 2002. Governmentality and regional economic strategies. In Jean Hillier and Emma Rooksby, eds., Habitus: A Sense of Place. Aldershot: Ashgate Publishing Limited.

Patmore, Greg. 2006 Employee representation plans in the United States, Canada, and Australia: An employer response to workplace democracy. Labor: Studies in Working-Class History of the Americas 3(2):41-65.

Penty, Rebecca. (2012). Deloitte proposes fixes for oilsands labour woes. Calgary Herald. Accessed 17 February 2012 at http:// www.calgaryherald.com/business/Deloitte+proposes+fixes+ oilsands+labour+woes/6154831/story.html\#ixzz1niAHkAQH.

Raco, Mike. 2009. From expectations to aspirations: State modernisation, urban policy, and the existential politics of welfare in the UK. Political Geography 28:436-444.

Rees, Jonathan H. 2010. Representation and Rebellion: The Rockefeller Plan at the Colorado Fuel and Iron Company, 1914-1942. Boulder, CO: University Press of Colorado.

Rose, Nikolas. 1996. The death of the social? Re-figuring the territory of government. Economy and Society 25:327-356.

Smith, Neil. 1990. Uneven Development: Nature, Capital, and the Production of Space. Oxford: Blackwell.

Stanford, Jim. 2011. A July 1 portrait of corporate Canada. Accessed 1 July 2011 from http://www.progressive-economics.ca/2011/06/29/a-july-1-portrait-of-corporate-canada/.

Statistics Canada 2006. Community highlights for the Regional Municipality of Wood Buffalo. Accessed 29 September 2008 and 28 September 2009 from http://www12.statcan.ca/english/census06/data/profiles/community $/$ Details/Page.cfm?Lang $=$ E\&Geo $1=$ CSD\&Code $1=4816037 \&$ Geo $2=\mathrm{P}$ $\underline{\mathrm{R} \& \text { Code } 2=48 \& \mathrm{Data}=\text { Count } \& \text { SearchText }=\text { fort } \% 20 \text { mcmurray } \& \text { SearchT }}$ ype $=$ Begins $\&$ SearchPR $=01 \& B 1=$ All\&Custom .

2012. Family income and income of individuals, related variables: Subprovincial data, 2010. The Daily, June 27.

Steele, D.H., R. Andersen, and J.M. Green. 1992. The managed commercial annihilation of northern cod. Newfoundland Studies 8:34-68. 
Vitalis, Robert. 2007. America's Kingdom: Mythmaking on the Saudi Oil Frontier. Stanford, CA: Stanford University Press.

Wilson, Lisa J. 2004. Riding the resource roller coaster: Understanding socioeconomic differences between mining communities. Rural Sociology 69(2):261-281.

Wright, M. 2003. Newfoundland and Labrador History in Canada, 1949-1972. Paper prepared for the Royal Commission on Renewing and Strengthening Our Place in Canada. http://public.gov.nl.ca/publicat/royalcomm/ research/history.pdf.

Wolf, Eric R. 1997 [1982]. Europe and the People without History. Berkeley, CA: University of California Press.

Claire Major is a PhD candidate in geography at York University. Her research interests include social reproduction, resource towns, urbanization and urban governance, labour, and social class. Her recent publications include, in 2011 with Roger Keil, "SARS and service work: Infectious disease and racialization," in A. Baldwin, L. Cameron, and A. Kobayashi, eds., Rethinking the Great White North: Race, Nature and the Historical Geographies of Whiteness in Canada. ctpmajor@gmail.com

Tracy Winters is a PhD candidate in Anthropology at Memorial University. Her research is on class, migration, and Newfoundlander diaspora in Fort McMurray, Alberta.

tracyhache@gmail.com 
